\title{
PRANCŪZŲ KALBOS MOKYMO(SI) METODAI: KARIAI, MUITININKAI, PRANCŪZŲ KALBOS STUDENTAI
}

\author{
Dr. Miroslav Stasilo \\ Generolo Jono Žemaičio Lietuvos karo akademija \\ Vilniaus universitetas
}

\begin{abstract}
Anotacija. Poreikis orientuotis ị visumini mokymąsi (intelektiniu, socialiniu ir emociniu aspektu vystymasis mokymo procese) akcentuotas jau praejusio amžiaus antrojoje puseje. Šiuolaikiniai tyrimai pateike dar daugiau visuminio mokymosi svarbos argumentu (Gardner H., Hatch T., Laird D., Terenzini P. Šiuolaikinio Lietuvos Respublikos švietimo pagrindinés tendencijos susijusios su mokymo(si) visa gyvenima politikos igyvendinimu). Tai padidino užsienio kalbu populiaruma, kuris nusileidžia tik informaciniu bei komunikaciniu technologiju plètrai. Tai atsispindi pagrindinèse švietimo formose (formalusis ir neformalusis mokymas), kurios nulemia užsienio kalbu mokymo(si) tikslus, uždavinius, siekinius, nagrinejjamas temas, metodus. Suaugusiuju švietejo (andragogo) darbas nukreiptas ị ugdymo procesa, daugiausia dèmesio skiriant atitinkamy kalbos igūudžiu, pozityvaus besimokančio asmens mastymo formavimuisi, kürybingos ir darbingos atmosferos kūrimui ir komunikaciniu gebejimu plètrai. Kiekviena edukacinè situacija yra daugialypé ir kompleksiška, ypač mokant profesinès prancūzu kalbos karius ar muitininkus. Muitinès mokymo centras naudoja kombinuotaji metoda, jungiantị tradicinius ir naujoviškus mokymo stilius. Generolo Jono Žemaičio Lietuvos karo akademija, kuri nenaudoja šio metodo mokant prancūzu kalbos, turi mokomosios medžiagos, tokios kaip vadovéliai karine tematika. Tokia medžiaga prisideda prie mokymo proceso efektyvumo gerinimo. Vilniaus universitetas remiasi tradiciniais metodais siekdamas paruošti būsimus lingvistus arba prancūzų kalbos mokytojus. Formalaus ir neformalaus ugdymo tikslai yra panašūs - padèti besimokančiam asmeniui pasinaudoti sparčiai besivystančios informaciniu technologiju visuomenès galimybèmis, priimant modernaus pasaulio iššukius: globalizacija, kompiuterizacija, ekonominiai ir socialiniai pokyčiai, visuomenès diferenciacija ir hierarchizacija.
\end{abstract}

Pagrindiniai žodžiai: formalusis ir neformalusis mokymas, užsienio kalbųmokymo(si) metodai, Lietuvos karo akademija, Muitinès mokymo centras, Vilniaus universitetas. 
Ivadas. Modernus žmogus, siekiantis tobulèti ir pagerinti savo gyvenimo kokybę, turi mokèti ịvairių užsienio kalbų, tarp kurių būtų labiausiai paplitusių pasaulyje. Viena iš jų yra prancūzų kalba, kuri labiausiai paplitusi po kinų, anglų, indų ir ispanų. Šiame procese suaugusiam žmogui ị pagalbą ateina andragogas (mokymo ir mokymosi „vedlys“), kurio darbas ir reikalavimai tampa vis sudettingesni, kadangi šiuolaikinè mokslo ir švietimo disciplina veikiama kitu mokslo sričių: kalbotyros, psichologijos, sociologijos, sociolingvistikos, informacinių technologijų. Su naujų technologijų atsiradimu užsienio kalbų dèstyme pastebimas dèmesio nukrypimas nuo metodologinès pusès, kuri lemia darbo efektyvumą ir rezultatų pasiekimą, prie technologinio proceso apipavidalinimo, kuris padeda pritraukti besimokančių asmenų dèmesị prie dèstomo dalyko, bet kartais atitolina nuo konkrečių tikslų, numatytų mokymo programoje, pasiekimo.

Tyrimo tikslas: aptarti ir palyginti neformaliojo ir formaliojo prancūzų kalbos mokymo programas ir metodus, naudojamus Lietuvos karo akademijoje (LKA), Muitinės mokymo centre (MMC) ir Vilniaus universitete (VU).

Tyrimo objektas: prancūzų kalbos dėstymas suaugusiems ir ịvairių metodų taikymas.

Tyrimo metodai: anketinè apklausa, literatūros analizè, deskriptyvinis metodas ir sisteminè duomenų analizè.

Mūsų kokybiniam tyrimui, paremtam moksline literatūra, internetine medžiaga ir asmenine darbo patirtimi nuo 2004 iki 2015 metų, taikomas deskriptyvinis metodas - aprašomos ịvairios mokymo programos ir joms vykdyti naudojamos mokymosi priemonès. Mes taikome taip pat lyginamaji metodą - sisteminis duomenų grupavimas, ieškant panašumų ir skirtumų, tarpusavio ryšių, atsakant į aukščiau pateiktus klausimus.

Tyrimo uždaviniai: atsakyti ị klausimus: „Kuo skiriasi formalusis ir neformalusis suaugusiųjų švietimas, tobulinant užsienio kalbų žinias?“, „Kokie veiksniai lemia efektyvų prancūzų kalbos mokymą(si)?“, „Kuo skiriasi andragogo darbas su kariais, muitininkais ir studentais?“

\section{Modernaus užsienio kalbų mokymo(si) apžvalga}

Šiandien pagrindinis dèmesys nukreiptas ị komunikacinių gebėjimų lavinimą. Komunikacinis užsienio kalbų mokymas integruoja geriausias kitų metodų ypatybes. Šiuolaikinis mokymo(si) procesas yra aktyvi paties individo veikla. Bendrinès prancūzų kalbos, kurią studijuoja ir kurios mokosi Vilniaus universiteto studentai, ir profesinès (muitinès ar kariuomenès) terminijos, kurią turi įsisavinti ir naudoti LR muitinès pareigūnai ir kariai, dèstymas turi bendrą uždavinį - išmokyti bendrauti prancūziškai. Komunikacinis metodas padeda išvengti interferencijos, suvokti ir įsiminti medžiagą, formuluoti produktyviosios kalbos gebejjimus.

Kiekvienas ankstesnis metodas palieka savo žymę užsienio kalbų mokyme(si), o tai, kas nauja, labai dažnai yra sena, tik paremta vis naujomis teorijomis. Visada 
yra naudinga susipažinti su metodų vystymosi istorija. Užsienio kalbų metodinėje literatūroje ${ }^{1}$ beveik visuomet istorinè metodų apžvalga pradedama nuo gramatiniovertimo metodo pristatymo, ilgiausiai (nuo XVI a. iki XX a.) išsilaikiusio mokymo praktikoje. Vokietijoje toks metodas dar vadinamas Olendorfo, o Amerikoje - ,prūsiškuoju“ metodu. Apžvelkime, koks tada vyravo požiūris ị kalbą ir studijuojamos kalbos šalies kultūrą, koks buvo mokytojo ir mokinio santykis, mokomoji medžiaga, jos pateikimas, kokią vietą užsienio kalbos mokymo procese užèmė gimtoji kalba. Paskui aptarsime ir kitų labiausiai paplitusių Europoje metodų pagrindinius bruožus.

Kalba buvo suprantama kaip taisyklių ir išimčių visuma. Su studijuojamos kalbos šalies kultūra buvo susipažįstama verčiant literatūrinius tekstus. Mokant kalbos buvo akcentuojama gramatika. Ypatingas demesys skiriamas gramatikos taisyklių išmokimui, linksniavimui, asmenavimui, sudetinių sakinių sudarymui, vertimui iš užsienio (dažniausiai lotynų ir graikų) i gimtają kalbą ir atvirkščiai. Turinys atsidurdavo antrame plane, nors labai svarbus išlikdavo literatūrinių tekstų supratimas. Svarbiausias dėmesys buvo skiriamas skaitymui ir rašymui, bet ne kalbejjimui, klausymui ar taisyklingam tarimui.

Mokytojas turejjo būti autoritetingas žinių perteikèjas, nes jis valdè visą mokymo procesą. Mokinys neturèjo rodyti savo iniciatyvos ir negalejjo klysti. Mokinio padaryta klaida turejjo būti tuoj pat ištaisyta. Interakcija „mokytojas-mokinys“ buvo vienakryptè. Mokomają medžiagą parinkdavo mokytojas, ịtraukdamas i ją literatūrinius tekstus, kurdamas gramatinius pratimus ir formuluodamas klausimus. Gimtosios kalbos svarba atsispindejo mokymo(si) procese - literatūriniai tekstai buvo verčiami ị gimtają kalbą ir atvirkščiai, taisyklès aiškinamos taip pat gimtąja kalba.

Kitas labai paplitęs Europoje XIX a. pab. - XX a. pr. metodas vadinamas tiesioginiu metodu (pranc. méthode directe). Čia kalba buvo suprantama kaip praktinè bendravimo raštu ir žodžiu priemonè. Kultūra nebuvo tapatinama tik su literatūra. Ji apimdavo platesnị vertybių spektrą, reiškinius, kuriuos buvo mėginta paaiškinti tarpkalbiniu (tarpkultūriniu) aspektu, pvz., kaip atrode prancūzų ir lietuvių darbo diena. Kalbos mokymas(is) numatydavo mokymąsi tiek kalbèjimo, klausymo, skaitymo ir rašymo, bet pastarosioms dviem kompetencijoms ugdyti buvo skiriamas mažesnis dèmesys. Nuo pat pradžių buvo mokoma taisyklingo tarimo ir vengiama vertimo. Didelis dèmesys buvo skiriamas leksikos mokymui(si). Buvo kuriamos tipinès situacijos: pašte, restorane, pas gydytoją ir pan. Gramatika tapdavo nebe tokia svarbi, bet mokytojas savo nuožiūra galèjo pateikti ịvairaus pobūdžio pratimų.

Mokytojas vadovavo mokymo procesui, bet mokinio iniciatyva jau buvo sveikintina. Mokinys neturejo būti pasyvus, jis privalèjo dalyvauti mokymo procese, galëjo užduoti klausimus, tikslintis jam neaiškius dalykus, tačiau pačiu mokinių sąveikos dar nebuvo. Mokytojas suteikdavo galimybę pasitaisyti mokiniui, pvz.,

1 Stasilo, M.; Valiukienè, V. (2013). Andragoginiai pranūzų kalbos mokymo metodai. Vilnius: Ugdymo plètotės centras. 
pakartoti neteisingai suformuluotą jo sakini ir po to pasakydavo teisingą variantą. Mokinys rinkdavosi iš kelių variantų. Mokytojo intonacija išduodavo, ar mokinys suklydo. Mokymo priemonès (vadovèliai) buvo labai svarbūs, bet mokytojas išlikdavo pagrindiniu žinių perteikejju ir kalbos, kurios mokoma, gyvu atstovu. Labai dažnai buvo naudojami paveikslèliai arba kitos vaizdinès pasparos.

$\mathrm{XX}$ a. vid. atsirado ir plačiai naudojamas iki šiol audiolingvistinis metodas (pranc. méthode audio-orale) arba „armijos“ metodas (pranc. méthode de l'armée). Šiam metodui būdingas universalios kalbos prigimties neigimas, nes teigiama, kad kiekviena kalba turi savitą fonologinę, sintaksinę, morfologinę sistemą. Kalba suprantama tik kaip komunikavimo priemone, jos pagalba pateikiamas kultūrinis tos šalies, kurios kalba studijuojama, kontekstas. Kalba laikoma ịgūdžių sistema. Kalbos mokoma tokia tvarka: klausymas, kalbejjimas, skaitymas, rašymas. Leksikai aiškinti skiriamas mažesnis dėmesys nei sintaksinèms struktūroms mokyti imitacijos būdu atliekant daug ịvairių pratimų. Naudojami taip pat ịvairūs substituciniai ir transformaciniai pratimai. Jie pateikiami sistemingai nuo lengviausio iki sunkiausio. Akcentuojama kalbos forma, funkcinis (semantinis) aspektas nèra reikšmingas.

Mokytojo ir mokinio santykyje jau pastebima interakcijos ,,mokytojas-mokinys" bruožų, bet vis dèlto mokytojas dar pati svarbiausia figūra. Jo pagrindinis vaidmuo - taisyti klaidas. Tarimo ir struktūros netikslumai taisomi iš karto. Mokytojas yra informacijos šaltinis, o garso įrašai tampa pačiu svarbiausiu mokymo ịrankiu. Mokytojas yra taisyklingo tikslinès kalbos tarimo pavyzdys, jo kalbą turi imituoti mokiniai. Siekiant išvengti gimtosios kalbos interferencijos rekomenduojama mokant vartoti tik tikslinę kalbą, tačiau aiškindamas mokytojas visada gali pasitelkti vaizdinę medžiagą, gestus, mimiką ir pan.

Radijo ir telelvizijos atsiradimas bei paplitimas mūsu gyvenime išpopuliarino audiovizualinị metodą (pranc. méthode audiovisuelle) (XX a. II pusè). Čia kalba yra suprantama kaip bendravimo žodžiu priemonè. Tai akustinis-vizualinis derinys. Kalba traktuojama kaip puikus kultūros vektorius. Šnekamoji kalba (ne literatūrinè) yra pirmame plane. Besimokant kalbos, didžiausias dèmesys skiriamas klausymo kompetencijos ugdymui, po to seka produkavimas žodžiu, vèliau skaitymas ir produkavimas raštu. Laikomasi tokio principo: kad būtų galima produkuoti, visų pirma, reikia ugdyti recepcinius gebejjimus. Svarbus tampa afektyvinis veiksnys, susidomima besimokančio asmens emocijomis, nuotaika, todèl svarbesniais tampa šnekos aktai, o ne enciklopedinès žinios apie kalbą kaip sistemą.

Mokytojas tampa mokymo proceso organizatoriumi, tačiau tai nereiškia, kad mokinys yra pasyvus: jis turi klausyti, kartoti, suprasti, atsiminti, kalbèti. Be to, garso ir vaizdo medžiaga šiek tiek ardo mokytojo ir mokinio hierarchinius santykius. Mokytojo požiūris ị klaidą nèra vienareikšmis. Klaidos imamos po truputị atpažinti: kompetencijos, atlikties. Kadangi svarbus afekto veiksnys, dažnai klaida suprantama, kaip susijaudinimo pasekmè ir pan. Mokytojas turi būti labai kūrybingas: turi ne tik taisyti tarimą, aiškinti gramatiką, bet kurti užduotis situaciniams dialogams, remdamasis vaizdo ir garso medžiaga. Be vadovèlio, labai svarbi yra garso ir vaiz- 
do medžiaga. Vaizdinè paspara pateikiama statiška (paveikslèlis) arba nurodomas dialogo kontekstas. Audiovizualinès priemonès išstumia rašytinị dokumentą. Gimtoji kalba traktuojama kaip interferencijos šaltinis, todèl mokymo procese rekomenduojama tik tikslinė kalba.

Šiuo metu didžioji užsienio kalbų mokymo programų dauguma (tarp jų VU, LKA ir MMC) akcentuoja komunikatyvinio metodo (pranc. approche communicative) (XX a. pab. - XXI a. pr.) naudojimą. Kalba suvokiama kaip dvasinè kūrybinè veikla ir raiška. Svarbiausia ne kalbos forma, o jos turinys ir funkcija. Ypatingas dèmesys skiriamas tarpkultūriam aspektui. Mokant kalbos ugdomi visų kalbinių veiklos rūšiu gebejjimai. Siekiama kuo daugiau mokymo procese remtis mokinio asmenine patirtimi. Daug demesio skiriama mokymo ir mokymosi strategijoms ugdyti(s). Mažiau dẻmesio skiriama ịgūdžiams treniruoti ir kaupti. Gramatika suprantama kaip reikalinga supratimui ir būtina kalbejjimui kompetencija. Lingvistinè kompetencija yra tik viena iš komunikacinès kompetencijos subkompetencijų (šalia sociolingvistinès, diskursinès, strateginès, sociokultūrinès). Mokymosi procesas yra grịstas užduotimi - vaidmenų žaidimais, autentiškų ir realių gyvenimiškų situacijų simuliavimu, problemų sprendimu ir pan. Mokinys aktyvus, žinantis savo poreikius ir motyvuotas. Mokytojas atlieka padejjejo vaidmeni. Sąveika „mokytojas-mokinys“ yra abipusė.

Mokant ir besimokant, rekomenduojami autentiški šaltiniai ir tikslinè kalba, tačiau gimtosios kalbos nèra visiškai atsisakoma. Požiūryje ị klaidą atsiranda terminas „tarpukalbės klaida“. Artedami link tikslinès kalbos, mokiniai gali klysti, bet mokytojo padedami, turi patys stebèti mokymosi procesą ir bandyti daryti išvadas. Komunikacinio metodo ar metodu pagrindu buvo sukurta daugelis mokymosi metodikų ${ }^{2}$ : Curan (1972) konsultuojamo mokymosi arba bendruomeninio kalbos mokymosi metodika (pranc. méthode communautaire); Cattegno (1972) tylos metodika (pranc. méthode par le silence), kai daug dèmėsio skiriama individualiam skaitymui, akcentuojant kalbos pajautimą; Ascher (1977) kalbos kaip visiško fizinio atsako metodika (pranc. méthode par le mouvement); Lozanovo (1979) sugestopedija (pranc. méthode suggestopédique); Krashen-Terrell (1983) natūralaus požiūrio metodika (pranc. approche naturelle).

Visos metodikos vienaip ar kitaip akcentuoja komunikacinių tikslų pasiekimą, dèmesį besimokančio asmens poreikiams. Tačiau studentų, ką tik baigusių vidurinę mokyklą, planuojančų susieti savo būsimą darbą ir gyvenimą su prancūzų kalba, ir suaugusių, turinčių nemažą profesinès patirties bagažą, kuriems prancūzų kalba yra tik vienas iš įrankių pagerinti arba pakeisti savo gyvenimo sąlygas ir kokybę, poreikis skiriasi iš esmès. Dažnai apsiribojama ịvertinimu klasès arba besimokančių asmenų grupès mastu, kas nèra teisinga, nes mokymo metodų ir būdų pasirinkimas remiasi visa sistema, t. y. dirbdami su VU studentais, turime atsižvelgti ị visą formaliojo aukštojo mokslo sistemą, o darbas su LR karininkais ar muitininkais priklauso nuo neformaliojo mokslo specifikos Lietuvoje.

2 Besse H. (1985). Méthodes et pratique manuels de langues. Paris: Didier; Galisson R. (1980). D'hier à aujourd'hui. La didactique générale des langues étrangères. Du structuralisme au fonctionnalisme. Paris: CLE International. 


\section{Formalusis ir neformalusis mokymas}

Prancūzijos ir Europos politikas, ekonomistas Žakas Deloras (Jacques Delors), Europos Sajungos integracijos proceso iniciatorius ir Europos Konvento 2002-2004, rengusio Europos Konstituciją, pirmininkas, yra sakęs, kad žmonėms moderniame pasaulyje svarbu ne tik mokytis pažinti, dirbti ir veikti, bet ir mokytis gyventi ir būti $\mathrm{kartu}^{3}$. Šiuolaikinị požiūrị ị suaugusiųjų švietimo paskirtị Lietuvoje galima apibrèžti trimis lygmenimis: konceptualiuoju, istatymu ir strateginiu. Išskiriamos dvi kryptys: 1) suteikti suaugusiam žmogui galimybę plètoti savo pasirinktos profesijos igūdžius, mūsų atveju - karininko, muitininko ar prancūzų kalbos specialisto; 2) leisti asmeniui dẻl ịvairių gyvenimo aplinkybių arba dẻl individualių paskatų keisti savo veiklos krypti, profesiją, pvz., LR muitinèje yra nemažai buvusių mokytojų.

Suaugusiujų švietimo svarba buvo pažymèta jau Lietuvos nepriklausomybės atkūrimo pradžioje 1992 metais. Mokymosi visą gyvenimą politika yra bendros švietimo politikos Lietuvoje dalis. Šiame dokumente akcentuojamos dvi švietimo organizavimo formos: 1) formalusis mokymasis, ir 2) neformalusis suaugusiuju švietimas. Prancūzų kalbos studijos VU yra formaliojo mokymo(si) dalis, o kitos dvi programos (LKA ir MMC) įeina ị neformaliojo suaugusiųjų švietimo Lietuvoje koncepciją ir susijusios su mokymosi visą gyvenimą politikos igyvendinimu.

Formalusis suaugusiųjų mokymasis gali būti apibūdintas: 1) pagal paskirtị (pradinis, pagrindinis ir t. t.); 2) pagal legitimaciją (lavinimo, mokymosi studijos, reglamentuojama ir kontroliuojama valstybès); 3) pagal vykdymą (VU, LEU, MRU ir t. t., t. y. aukštajį išsilavinimą ir kvalifikaciją teikianti institucija). Formalųj švietimą apriboja mokymo laikas, mūsų atveju - 4 metai, mokomieji dalykai (literatūros istorija, šiuolaikinè prancūzų kalba, kalbotyra, filosofija, stilistika ir t. t.) ir vieta (VU). Akcentuojamas konkretus rezultatas, žinios (studentai rašo kontrolinius darbus, atsiskaito, laiko ịskaitas ar egzaminus, jie gauna galutinị ịvertinimą sesijos metu). Baigus formaliojo ugdymo ịstaigą yra suteikiamas oficialiai pripažįstamas išsilavinimą patvirtinantis dokumentas, mūsų atveju - prancūzų filologijos bakalauro diplomas.

Neformalusis suaugusiųjų mokymasis gali būti apibrèžtas taip pat trimis parametrais: 1) pagal paskirtị (žmogaus savarankiškas mokymasis, kurio tikslas - mokytis visą gyvenimą, tenkinant asmeninius pažinimo poreikius, tobulinant igytą ar igyjant naują išsilavinimą); 2) pagal legitimaciją (lavinimo, mokymosi, studijų procesas, kurio rezultatas įvertinamas išsilavinimą liudijančiu dokumentu, išduodamu vykdančios šią veiklą organizacijos - LKA, MMC); 3) pagal vykdymą (neformaliojo švietimo anksčiau nevykdè formalios mokymo ịstaigos, bet situacija keičiasi, pvz., LKA organizuoja prancūzų kalbos kursus kariams, vykstantiems ị tarptautines operacijas). Neformalusis suaugusiujų mokymas - kryptinga veikla, kuria siekiama ugdyti sąmoningą asmenybę, sugebančią atsakingai ir kūrybingai spręsti savo problemas ir aktyviai dalyvauti visuomenès gyvenime.

3 Delors J. (2007). L'Europe tragique et magnifique: Les grands enjeux européens. Saint-Simon. 


\section{Prancūzų kalbos programų palyginimas}

Užsienio kalbos yra viena greičiausių ir dinamiškiausių naujovių Lietuvos visuomeneje ir jos švietimo sistemoje. Formaliojo ir neformaliojo mokslo tikslas padèti kuo plačiau pasinaudoti atsiveriančiomis naujomis galimybèmis ir atsakyti i pagrindinius modernaus pasaulio iššūkius: globalizacija, informacijos kiekio ir greičio augimas, spartus ekonominiai, politiniai ir socialiniai pasikeitimai, visuomenès išsiskaidymas. Pedagogas ar andragogas turi nepamiršti šio esminio tikslo ir detalaus mokymo(si) situacijos analizavimo: 1) užsakančios institucijos ir visuomenès poreikis ir reikalavimai, 2) būsimų studentų lūkesčiai, 3) sociokultūrinis besimokančių asmenų ir andragogo ryšis, 4) kalbiniai ịgūdžiai, reikalingi būsimiems studentams, 5) komunikacijos situacijos, su kuriomis reikia susipažinti ir kurias reikia ịvaldyti, 6) galimos specifinès profesinès sritys, 7) finansiniai ir žmogiškieji ištekliai bei apribojimai, 8) mokymams skiriamas laikas, 9) edukacinė aplinka, 12) socialinè ir kultūrinè situacija ${ }^{4}$. Šios užduoties tikslas - ịvertinti mokymo procesą kompleksiškai, t. y. ižiūrèti svarbiausius konkrečios mokymo(si) situacijos elementus ir jų tarpusavio ryšius pirmiausia švietimo sistemos rèmuose, paskui pereiti į žemesnị organizacijos ar struktūros lygị ir tik pačioje įvertinimo pabaigoje pereiti prie konkrečios grupès laiptelio.

Akivaizdu, kad prancūzų kalbos formalusis ir neformalusis mokymas turi bendrų bruožų, pvz., abiejų sistemų tikslas - ugdyti komunikacinius, informacinius ir socialinius gebejjimus ir lavinti klausymo, kalbejjimo, skaitymo, rašymo kompetencijas, supažindinti su kai kuriais kultūros bruožais; metodai - diskusijos, situaciniai žaidimai, praktinio pobūdžio, užduočių atlikimas (individualiai, poromis arba grupèmis), praktiniai-operaciniai igūdžių ịtvirtinimo ir kartojimo metodai. Visų kalbinès praktikos rūšių mokoma susietai. Tačiau yra skirtumų, kadangi kiekvienos veiklos lyginamasis svoris kinta atsižvelgiant ị mokymosi sąlygas. Pirmasis klausimas, kurị užduoda sau andragogas, ruošdamas prancūzų kalbos mokymus formaliojo ar neformaliojo mokymo sistemos rèmuose būtų: „Kokie yra mokymo tikslai?““

Palyginkime VU, LKA ir MMC programas: „Ugdyti sakytinès ir rašytinès kalbinès veiklos (klausymo, kalbejjimo, skaitymo, rašymo) ịgūdžius, ugdyti komunikacinę kompetenciją, supažindinti su kai kuriais kultūros bruožais. Ugdyti gebėjimą suvokti ir analizuoti prancūzų kalbos gramatikos reiškinius, ugdyti analitinị mąstymą.“ (žr. VU, „Šiuolaikiné prancūzų kalba 1 [pradedantiesiems]“). ,[...] ugdyti Krašto apsaugos sistemos karių prancūzų kalbos komunikacinius ir socialinius gebejjimus, kurie padètų vykdyti pareigas bei atlikti užduotis“ (žr. LKA, „Prancūzų kalbos kursų programa kariams, vykstantiems ị tarptautines operacijas“). ,[...] ugdyti muitinès sistemos darbuotoju komunikacinius, informacinius bei socialinius gebejjimus“ (beje, analogiški tikslai surašyti ir kitose programose, tarp kurių kombinuoto prancūzų kalbos mokymo programa, žr. MMC „Mokymo programos“5).

Balmet S. E., Henao de Legge M. (1992). Pratiques du français scientifique. HACHETTE. P. 11.

5 Prieiga per internetą: http://www.cust.lt/web/guest/609. 
Matome, kad LKA ir MMC mokymo tikslai labai panašūs, tačiau VU tikslai papildyti analitinio mąstymo (analizè, sintezè, palyginimas, apibendrinimas, konkretizavimas) ir gramatikos reiškinių (prancūzų kalbos morfologija, sintaksè, leksikologija) ịvaldymo svarba. Tai susiję su formaliojo ir neformaliojo mokslo specifika (žr. viršuje) ir su skirtingais analizuojamų auditorijų lūkesčiais. VU Bakalauro studijos ,suteikia bendrajji universitetinį išsilavinimą ir ugdo bendrąsias ir pasirinktos studijų krypties dalykines kompetencijas. Baigus tam tikros studijų krypties (šakos) bakalauro studijas suteikiamas tos krypties (šakos) bakalauro kvalifikacinis laipsnis [...] Studentas - tai asmuo, sudaręs studijų sutartị su Universitetu, įrašytas ị Universiteto studentų registrą ir studijuojantis pagal studijų programas arba doktorantūroje [...] Studijų dalykas - tai mažiausia studijų programos turinio dalis, turinti apibrèžtą tikslą ir orientuota ị studijų siekinius, ugdanti bendrąsias ir (ar) dalykines kompetencijas, reikalingas ịgyti kvalifikacinị laipsnị. Kiekvieno dalyko (modulio) studijos baigiamos egzaminu arba studento savarankiškai atlikto mokslo tiriamojo darbo (projekto) ịvertinimu“ (žr. VU „Studijų nuostatai““).

Analizuojami LKA ir MMC klausytojai, turintys kvalifikacinius laipsnius (LR karininko ar muitininko), studijuoja prancūzų kalbą dèl asmeninių interesų, dažniausiai profesinių. Šiuo požiūriu karininkų ir muitininkų auditoriją vienija bendri profesiniai interesai ir poreikiai, kurie nulemia tam tikrų subkompetencijų buvimą arba nebuvimą mokymo procese. „Ugdydamiesi lingvistinę kurios nors kalbos subkompetenciją mokiniai turi galimybę susipažinti su kalbos sistemos dèsningumais, jos sandara, kalbos savitumu [...] Ugdantis sociolingvistinę subkompetenciją mokomasi vartoti ir interpetuoti kalbos formas pagal situaciją. Ugdantis diskursinę subkompetenciją mokomasi suprasti ir formuluoti rišlius ir aiškius sakytinius ir rašytinius tekstus, o ugdantis strateginę subkompetenciją mokomosi naudotis ịvairiomis strategijomis, siekiant suprasti klausomą arba skaitomą tekstą, kuriant savo tekstą raštu arba žodžiu, bendraujant su pašnekovu. Ugdantis sociokultūrinę subkompetenciją siekiama suvokti sociokultūrinị kontekstą, kuriame ši kalba vartojama." 7

LKA ir MMC klausytojams akcentuojamos sociokultūrinè ir strateginè subkompetencijos. Tai galima pastebėti gvildenamų temų sąraše. Palyginkime LKA ir MMC prancūzų kalbos programas: „1. Kario kasdieninis gyvenimas. 2. Kario tarnybos vietos pristatymas. 3. Bendravimas su vietiniais gyventojais. 4. Kariné amunicija ir ginkluotè. 5. Ginklų valdymo komandos. 6. Karių funkcijos ir uždaviniai. 7. Pagrindinès rikiuotès komandos. 8. Kariniai laipsniai ir uniformos. 9. Kariniai padaliniai. 10. Sveikata.“ (žr. LKA, „Prancūzų kalbos kursų programa kariams, vykstantiems ị tarptautines operacijas“). „16.1. Asmeninè informacija. 16.2. Šalys ir tautybès. 16.3. Šeima. 16.4. Darbas. 16.5. Darbo vietos įranga. 16.6. Kasdieninè veikla. 16.7. Miestas. 16.8. Būstas. 16.9. Maistas ir gèrimai. 16.10. Spor-

\footnotetext{
6 Prieiga per internetą:

http://www.vu.lt/site_files/SD/Studentams/SP/SRD/VU_studiju_nuostatai_naujoji_redakcija.pdf.

7 Kalbų mokymo politikos aprašas (2006). Švietimo aprūpinimo centras. Vilnius. P. 128.
} 
tas. 16.11. Pokalbiai telefonu. 16.12. Šventès ir tradicijos. 16.13. Parduotuvèje. 16.14. Kūno dalys. 16.15. Žmonių apibūdinimas. 16.16. Oras. 16.17. Jausmų apibūdinimas. 16.18. Oro uoste. 16.19. Viešbutis. 16.20. Laikas. 16.21. Muitinès sistema. 16.22. Muitinès postuose. 16.23. Muitinès kontrolè. 16.24. Prekès muitinèje. 16.25. Muitinès dokumentų pildymas. 16.26. Kontrabanda.“ (žr. MMC „Muitinès sistemos darbuotojų A1 lygio prancūzų kalbos mokymo programa“" $)$.

Abiejų neformalų mokymą organizuojančių institucijų temos reikalauja ịvairių strategijų taikymo ir tiesiogiai susijusios su sociokultūriniu kontekstu, su profesine veikla, kadangi formalusis ugdymas suteikia žmonėms akredituotą kompetencijų paketą, kuris reikalingas tolesnei karjerai, o neformalusis ugdymas dèl savo socialinio ir taikomojo pobūdžio suteikia kompetencijų, kurios leidžia žmonèms įsitraukti ị bendruomenès gyvenimą. Neformaliojo ugdymo įgytos kompetencijos padeda sèkmingiau įsitvirtinti darbo rinkoje, tačiau MMC temų sąrašas žymiai platesnis, kadangi kursai trunka 300 valandų ( 240 valandų auditorijoje ir 60 valandu besimokant savarankiškai). O LKA prancūzų kalbos kursų trukmè - 144 valandos (120 kontaktinių valandų, 16 individualaus klausymo ir 8 valandos konsultacijoms). Taip pat pastebime LKA temų ypatumą, susijusị su šių kursų siauresniu profesiniu orientavimu ị auditoriją, besiruošiančią išvykti ị tarptautines operacijas. Šiam tikslui pasiekti LKA turi labai svarbų privalumą - prancūzų kalbos vadovèlius karine tematika9.

Kalbos ịvaizdis, gautas išsilavinimas, naudojami vadovèliai - tai elementai, kurie turi įtakos gyventojų subjektyviam, kokybiniam kalbos vertinimui. Šiandieniné Lietuvos mokymo priemonių rinka yra labai didelè. Deja, nacionalinių prancūzų kalbos vadovèlių siūlomas asortimentas labai mažas, kadangi šiandien yra galimybė rinktis kokybiškas knygas, importuojamas iš Prancūzijos, Belgijos ir kitu prancūzakalbių šalių. Tai taip pat susiję su maža paklausa tokio tipo vadovèliams, sudarytiems ir išleistiems Lietuvoje. LKA šiuo atžvilgiu yra išimtis, nes išleido ne tik prancūzų, bet ir kitų (vokiečių, rusų) kalbų vadovèlius karine tematika. Kiekviena situacija yra kompleksiška, ypač kai dèstoma profesinè prancūzų kalba. Labai svarbu aukščiau pažymètus komponentus apmąstyti ir detaliai išanalizuoti. Igyvendinant Mokymosi visą gyvenimą strategiją labai padidejo užsienio kalbų kursų paklausa. Prancūzų kalbos dėstymas priklauso nuo besimokančių asmenų ir sistemos poreikio, besimokančių asmenų ir andragogo patirties ir motyvacijos.

MMC naudoja savo mokymuose kombinuotaji metodą, kuris jungia tradicinius (pvz., paskaita) ir modernius (pvz., interaktyvius) mokymo būdus. Šis metodas leidžia apmokyti LR muitinès darbuotojus neatitraukiant jų nuo darbo (70 \% mokymo sudaro nuotolinis mokymasis) ir atsižvelgiant ị besimokančiujų pageidavimus (mokymų kuratorius turi prieigą prie mokymo modulyje skelbiamos mokomosios

\footnotetext{
$8 \quad$ Prieiga per internetą:

http://www.cust.lt/mport/failai/struktura_ir_kontaktai/muitines_mokymu_centras/mokymo_programos/kalbos/ Muitines_sistemos_darbuotoju_prancuzu_k_A1_Decouverte_A1_2007_01_25.pdf.

9 Jarutienė A. (2014). Le français pour les militaires. Generolo Jono Žemaičio Lietuvos karo akademija; Mraz C. (2011). En avant. Paris.
} 
medžiagos, kurią gali pakeisti arba papildyti). Rengdama prancūzų kalbos mokymus, kurso pabaigoje MMC išdalina savo klausytojams anketas, kur du klausimai susiję su besimokančių asmenų lūkesčiais: „Kokie buvo jūsų lūkesčiai prieš atvykstant ị mokymus?“, „Ar mokymai patenkino jūsų lūkesčius?“. Kiti klausimai susiję su edukacinio proceso įvertinimu: „Kaip vertinate kursus?“, „Ar visos temos naudingos jūsų darbui?“, „Kokios temos jums labiausiai patiko?“”, „Kokias temas reikètų išbraukti?“”, „Ką galima būtų pridèti?“, „Ką patartumète dèstytojui pakeisti arba patobulinti?" ir pan. İdomų tai, kad prancūzų kalbos kursai buvo ịvertinti geriausiai 2010-2012 metais, t. y. tuo metu, kai MMC organizavo prancūzų kalbos kombinuotus mokymus. Iš 86 apklaustujų 76 įvertino kursus „labai gerai“, 8 - „gerai“ ir tik 2 dalyviai parašè ,vidutiniškai“.

\section{Išvados}

Užsienio kalbų mokymo(si) paklausa Lietuvoje auga, igyvendinant mokymo(si) visą gyvenimą strategiją. Formaliojo ir neformaliojo mokymo tikslas padèti besimokančiam asmeniui susiorientuoti šiuolaikinejje sparčiai besivystančiu naujujjų technologijų bei augančio informacinio srauto visuomenèje, suteikiant galimybę pasinaudoti atsirandančiomis naujomis galimybėmis ir atsakyti ị pagrindinius modernaus pasaulio iššūkius. Formalusis ugdymas suteikia žmonèms akredituotą kompetencijų paketą, o neformalusis ugdymas leidžia žmonėms įsitraukti ị bendruomenès gyvenimą.

Modernus mokymasis yra aktyvi paties besimokančio asmens veikla. Siekiant ugdyti komunikacinę kompetenciją ir sudarant sąlygas išsiugdyti kūrybingą, atsakingą, mąstančią, motyvuotą asmenybę, LKA, MMC ir VU naudoja ịvairius metodus - nuo paskaitos iki nuotolinio mokymo. Metodo pasirinkimas priklauso nuo organizuojančios formalujj arba neformalujj mokymą institucijos poreikio ir nuo paties švietejo patirties ir ryžto, taip pat nuo mokymo programos nuostatų. Andragogo darbas ir dèmesys nukreiptas ị numatytų programoje kalbinių kompetencijų pasiekimą, pozityvaus mąstymo formavimą ir ị edukacinio proceso vadovavimą. 


\section{Literatūra}

1. Balmet, S. E.; Henao de Legge, M. (1992). Pratiques du français scientifique.HACHETTE.

2. Besse, H. (1985). Méthodes et pratique manuels de langues. Paris: Didier.

3. Delors, J. (2007). L'Europe tragique et magnifique: Les grands enjeux européens.Saint-Simon.

4. Galisson, R. (1980). D'hier à aujourd'hui. La didactique générale des langues.étrangères. Du structuralisme au fonctionnalisme. Paris : CLE International.

5. Jarutienè, A. (2014). Le français pour les militaires. Generolo Jono Žemaičio Lietuvos karo akademija. Vilnius.

6. Kalbų mokymo politikos aprašas. (2006). Švietimo aprūpinimo centras.

7. Mokymo programos. [žiūrèta 2016-01-25]. Prieiga per internetą:

http://www.cust.lt/web/guest/609.

8. Mraz, C. (2011). En avant. Paris.

9. Muitines sistemos darbuotoju Al lygio prancūzu kalbos mokymo programa. [žiūrèta2016-01-25]. Prieiga per internetą: http://www.cust.lt/mport/failai/ struktura_ir_kontaktai/muitines_mokymu_centras/mokymo_programos/kalbos/ Muitines_sistemos_darbuotoju_prancuzu_k_A1_Decouverte_A1_2007_01_25.pdf.

10. Stasilo, M.; Valiukienè, V. (2013). Andragoginiai prancūzų kalbos mokymo metodai. Vilnius: Ugdymo plètotès centras.

11. Studijų nuostatai. [žiūrèta 2016-02-08]. Prieiga per internetą:

$\mathrm{http} / / /$ www.vu.lt/site_files/SD/Studentams/SP/SRD/VU_studiju_nuostatai_ naujoji_redakcija.pdf. 


\title{
FRENCH LANGUAGE TRAINING METHOD: SOLDIERS, CUSTOMS OFFICERS, FRENCH STUDENTS
}

\author{
Dr. Miroslav Stasilo \\ The General Jonas Žemaitis Military Academy of Lithuania \\ Vilnius University
}

\section{Summary}

The demand for teaching foreign languages increases through continuous Learning Initiative Strategy in Lithuania. This demand is lower than that related to computer technology. The objectives of formal and non-formal education are similar, i.e. helping learners to take advantage of new technological and social opportunities and meet the challenges of today's world: globalization, computerization, economic and social changes, differentiation and prioritization of society. Each educational situation is complex, especially in French teaching to military, customs or students.

Teaching and learning today is focused on communication which depends on learning needs and learners' autonomy, their experience and work styles. The work of an adult educator is to direct an educational process by focusing on training appropriate language skills, interaction, respect for others, formation of learners' positive thinking as well as the development of communicative ability. The main trends of modern education are related to teaching, learning and active policy of vocational training throughout life. The Customs Training Centre has a good reputation regarding the French language by the eLearning Method that combines traditional and innovative approaches. The Military Academy of Lithuania is not using this method but has good teaching materials, such as textbooks for the military that make teaching and learning French solid and effective. The Vilnius University uses traditional methods and aims to train a future researcher or teacher of the French language. The final choice of a method depends on the determination, motivation and skills of an adult educator. 


\section{AUTORIAUS LYDRAŠTIS}

Autoriaus vardas, pavardè: Miroslav Stasilo

Mokslo laipsnis ir vardas: Filologijos mokslų daktaras

Darbo vieta ir pareigos: Generolo Jono Žemaičio Lietuvos karo akademijos ir Vilniaus universiteto lektorius

Autoriaus mokslinių interesų sritys: kalbos, sociologija, politikos mokslai, etika

Telefonas ir el.pašto adresas: 8611 44811; francaisprancuzas@yahoo.fr

\section{AUTHOR'S COVER LETTER}

Author's name and surname: Miroslav Stasilo

Academic degree and name: Doctor of Linguistics

Workplace and position: The General Jonas Žemaitis Military Academy of Lithuania, Vilnius University, Lecturer

Author's research interests: language, sociology, political science, ethics

Telephone and e-mail address: + 37061144 811, francaisprancuzas@yahoo.fr 